\title{
Collagen Polymorphism in Idiopathic Chronic
}

\section{Pulmonary Fibrosis}

\author{
J. M. SEyer, E. T. Hutcheson, and A. H. Kang \\ From the Veterans Administration Hospital and the Departments of Biochemistry and \\ Medicine, University of Tennessee Center for the Health Sciences, \\ Memphis, Tennessee 38104
}

\begin{abstract}
A в S T R A C T Collagens in normal human lung and in idiopathic chronic fibrosis were investigated in terms of their covalent structure and compared for possible alterations in the diseased state. Collagens were solubilized by limited digestion with pepsin under nondenaturing conditions, and after purification they, were fractionated into types I and III. Carboxymethylcellulose and agarose chromatography of both types I and III collagens, and amino acid and carbohydrate analyses of the resulting $\alpha$-chains indicated that the $\alpha 1$ (I), $\alpha 2$, and $\alpha 1$ (III) chains of normal human lung were identical with the human skin $\alpha$-chains in all respects examined except that the normal lung chains contained higher levels of hydroxylysine.
\end{abstract}

Examination of collagens obtained from the diseased lung revealed that the content of hydroxylysine of the $\alpha 1$ (I) and the $\alpha 1$ (III) chains appeared to be diminished as compared to the normal lung chains. The values, expressed as residues per 1,000 residues, are 7.1 and 8.3 for the $\alpha 1$ (I) and the $\alpha 1$ (III) chains, respectively, as compared to 10.0 and 11.1 for the $\alpha$-chains from the normal tissue. The chromatographic properties and amino acid and carbohydrate composition of the $\alpha$-chains from the diseased tissue were otherwise indistinguishable from those of normal lung. In addition, isolation and characterization of the CNBr peptides of $\alpha 1(\mathrm{I}), \alpha 2$ and $\alpha 1$ (III) from the diseased lung revealed no significant differences from the $\mathrm{CNBr}$ peptides from other human tissues reported previously.

Normal and diseased lungs were also digested with $\mathrm{CNBr}$, and the resultant $\alpha 1$ (I) and $\alpha 1$ (III) peptides were separated chromatographically. The relative quan-

Dr. Kang is a Medical Investigator of the Veterans Administration.

Received for publication 19 September 1975 and in revised form 6 February 1976. tities of these peptides indicate that type III collagen constitutes $33 \%$ of the total collagen in normal human lung, with the remainder being type $I$, whereas in idiopathic chronic pulmonary fibrosis, the relative content of type III collagen is markedly diminished, ranging from 12 to $24 \%$ in different patients.

These results indicate that an alteration in tissue collagen polymorphism as well as subtle variations in the collagen structure accompany the fibrotic process in the diseased state, and suggest that these alterations may have possible pathogenetic implications.

\section{INTRODUCTION}

Connective tissue of lung is fundamental to the structural integrity and function of the organ $(1,2)$. Knowledge of the chemical nature and the properties of the connective tissue matrix elements in normal lungs, and their alterations in diseased organs is therefore essential to our understanding of the mechanisms involved in pathologic processes. Lung connective tissue is composed of collagen, elastin, and ground substances (3-5). Of these, collagen is the most abundant protein, comprising $11 \%$ of adult lung (6); it has the greatest tensile strength and probably plays an important role in the mechanical properties of lung $(7,8)$.

Recent studies from several laboratories have elucidated at least four genetically distinct collagens from various tissues (9). The most completely characterized and widely distributed in tissues is type I collagen. It is present in nearly all connective tissues, including skin, bone, tendon, aorta, and most parenchymal organs, and it is composed of two $\alpha 1$ (I) chains and one $\alpha 2$ chain, or $[\alpha 1(\mathrm{I})]_{2} \alpha 2(10,11)$. Type II collagen, consisting of $[\alpha 1(\mathrm{II})]_{3}$, is present solely in cartilage. Type III collagen, with the chain composition of $[\alpha 1 \text { (III) }]_{3}$ has recently been isolated from human skin, aorta, and leiomyoma (12-14). In addition, basement membranes 
of renal glomeruli and anterior lens capsules have been shown to contain type IV collagen, composed of $[\alpha 1$ (IV) $]_{3}(15,16)$.

The discovery of the existence of several genetically different collagens in the same tissue has made the questions concerning collagen polymorphism of both the normal and the diseased organs more cogent. In chronic pulmonary fibrosis, histologic evidence suggests that there is an increase in collagen in affected regions of the lung (17), but to our knowledge there has been no biochemical characterization of the protein in this fibrotic state. Recent work by Bradley et al. $(6,18,19)$ has indicated that explants from peripheral portions of normal lung synthesize type I collagen and explants of trachea and the bronchial tree synthesize type II collagen in tissue culture. In addition, type I collagen has been isolated and characterized from normal rabbit lungs (6). In this study, we report the isolation and characterization of type III and type I collagen from normal adult human lung and their behavior in chronic pulmonary fibrosis. Our results clearly indicate that in fibrotic lung the relative content of type III is markedly diminished, while the content of type $\mathrm{I}$ is increased. The degree of lysine hydroxylation seems to be also reduced in the $\alpha 1$ chains of type $\mathrm{J}$ and type III collagen in the diseased lung.

\section{METHODS}

Lung samples. Human lung was obtained from adults at the time of autopsy. Diseased lungs were taken from five males (ages 50-70) with idiopathic pulmonary fibrosis. The diagnosis was confirmed by histologic examination of autopsy samples. The normal lungs were obtained from male patients of similar ages as the diseased subjects, who had died of unrelated causes. Only the lungs without gross and microscopic evidence of acute or chronic disease processes were used in this study. All pathologic examinations were carried out by Dr. J. M. Young, Chief, Pathology Service, Memphis Veterans Administration Hospital. The tracheobronchial tissues were removed as much as possible by dissection. The remaining peripheral lung was cut into pieces, ground in a mechanical meat grinder, and homogenized briefly with a Waring blender at $4^{\circ} \mathrm{C}$ (Waring Products Div., Dynamics Corp. of America, New Hartford, Conn.). The homogenate was then washed with large

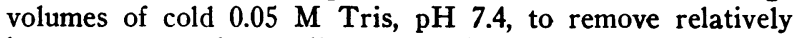
large amounts of noncollagenous substances, and finally with cold distilled water. The insoluble tissue residue, which contained over $99 \%$ of the original collagen as determined by hydroxyproline analysis (20), was collected by centrifugation and either used directly for pepsin digestion or $\mathrm{CNBr}$ clevage.

Solubilation of collagen by limited pepsin digestion and isolation of molecular species. The washed lung homogenate residue was suspended in cold $0.5 \mathrm{M}$ acetic acid, and the $\mathrm{pH}$ of the suspension adjusted to 2.5 by the addition of formic acid. All operations were performed at $4^{\circ} \mathrm{C}$. Pepsin was then added ( $1 \mathrm{~g} / 50 \mathrm{~g}$ wet weight) and digestion was allowed to proceed for $72 \mathrm{~h}$ with gentle shaking. The undigested residue was separated by centrifugation for $1 \mathrm{~h}$ at $10,000 \mathrm{~g}$, and digested two more times with pepsin under identical conditions. Collagen present in the three pepsin extracts was precipitated by dialysis against $0.01 \mathrm{M} \mathrm{Na}_{2-}$ $\mathrm{HPO}_{4}$ and harvested by centrifugation. The precipitate was redissolved in $0.5 \mathrm{M}$ acetic acid and precipitated again by the addition of $\mathrm{NaCl}$ to a final concentration of $1 \mathrm{M}$. The final precipitate was resolubilized in $0.05 \mathrm{M}$ Tris $/ 1 \mathrm{M} \mathrm{NaCl}$, $\mathrm{pH}$ 7.4. Type III collagen was then precipitated by a careful addition of $\mathrm{NaCl}$ to a concentration of $1.5 \mathrm{M}$ and collected by centrifugation $(12,14)$. Remaining collagen in the supernatant solution (predominently type I) was precipitated by increasing the $\mathrm{NaCl}$ concentration to $2.5 \mathrm{M}$. Each type of collagen was then dissolved in $0.1 \mathrm{M}$ acetic acid, dialyzed exhaustively against the same solution, and lyophilized.

Cleavage with cyanogen bromide. Samples of washed lung homogenates $(500-1,000 \mathrm{mg})$ were suspended in 50 $100 \mathrm{ml}$ of $70 \%$ formic acid. Samples of purified collagen chains $(50-200 \mathrm{mg})$ were dissolved in $20-50 \mathrm{ml}$ of $70 \%$ formic acid. The suspension or solution was flushed with nitrogen, and a weight of $\mathrm{CNBr}$ (Pierce Chemical Co., Rockford, Ill.) equal to two times the weight of the sample was added. Digestion was allowed to proceed for $4 \mathrm{~h}$ at $40^{\circ} \mathrm{C}$ with gentle stirring. Insoluble material, if any, was separated by centrifugation for $10 \mathrm{~min}$ at $40,000 \mathrm{~g}$, and the supernate containing the liberated peptides was lyophilized after a 10-fold dilution with cold distilled water. The extent of solubilization of collagenous protein by $\mathrm{CNBr}$ digestion was determined by hydroxyproline analysis of portions of the supernate and the residue.

Ion exchange chromatography. Separation of the constituent $\alpha$-chains of pepsin-solubilized collagen was achieved by chromatography of a heat denatured collagen solution on a column $(2.5 \times 10 \mathrm{~cm})$ of carboxymethylcellulose (CMcellulose $)^{1}$ (CM-52, Whatman, Inc., Clifton, N. J.) at $43^{\circ} \mathrm{C}$ (21). Samples were solubilized in $0.02 \mathrm{M}$ sodium acetate/ 1 $\mathrm{M}$ urea, $\mathrm{pH} 4.8$, denatured by warming the solution at $43^{\circ} \mathrm{C}$ for $20 \mathrm{~min}$, and applied to the column. The collagen chains were eluted with a linear gradient of $\mathrm{NaCl}$ from 0 to 0.1 $M$ over a a total volume of $1,200 \mathrm{ml}$. The effluent was monitored continuously at $230 \mathrm{~nm}$ in a Gilford recording spectrophotometer (model 2400S, Gilford Instrument Laboratories, Inc., Oberlin, Ohio) equipped with a flow cell, and collected in fractions of $10 \mathrm{ml}$. The fractions corresponding to each peak were pooled, desalted on a column $(4 \times 60 \mathrm{~cm})$ of Sephadex G-25 (Pharmacia Fine Chemicals, Inc., Piscataway, N. J.) using $0.1 \mathrm{M}$ acetic acid as the eluent, and lyophilized.

Peptides generated by $\mathrm{CNBr}$ digestion were chromatographed on a column $(0.9 \times 15 \mathrm{~cm})$ of $\mathrm{CM}$-cellulose at $43^{\circ} \mathrm{C}$ (22). Samples (50-100 $\mathrm{mg}$ ) were dissolved in $5 \mathrm{ml}$ of starting buffer $(0.02 \mathrm{~N}$ sodium citrate/0.02 M NaCl, $\mathrm{pH}$ 3.8) and applied to the column equilibrated with the same buffer. Peptides were eluted with a linear gradient formed between $250 \mathrm{ml}$ each of the starting buffer and limiting buffer $(0.02 \mathrm{~N}$ sodium citrate/ $0.16 \mathrm{M} \mathrm{NaCl}, \mathrm{pH} 3.8)$. A flow rate of $48 \mathrm{ml} / \mathrm{h}$ was used and the effluent was continuously monitored at $230 \mathrm{~nm}$. The fractions representing each peptide peak were pooled, lyophilized, desalted on Bio-Gel P-2 (Bio-Rad Laburatories, Richmond, Calif.) (100-200 mesh) using $0.1 \mathrm{M}$ acetic acid, and relyophilized.

Certain of the $\mathrm{CNBr}$ peptide fractions obtained from the initial CM-cellulose chromatography at $\mathrm{pH} 3.8$ required further fractionation at $\mathrm{pH} 4.8$. A column $(0.9 \times 10 \mathrm{~cm})$

\footnotetext{
${ }^{1}$ Abbreviation used in this paper: CM-cellulose, carboxymethylcellulose.
} 
of $\mathrm{CM}$-cellulose was equilibrated with starting buffer $(0.02$ $\mathrm{M}$ sodium acetate, $\mathrm{pH} 4.8$ ) at $43^{\circ} \mathrm{C}$, and after application of samples was eluted with a concave gradient prepared from $250 \mathrm{ml}$ of the starting buffer and $415 \mathrm{ml}$ of limiting buffer $(0.02 \mathrm{M}$ sodium acetate/0.16 $\mathrm{M} \mathrm{NaCl}, \mathrm{pH} 4.8)$ in a twochamber constant level device $(23,24)$.

Other peptide fractions were rechromatographed on a column $(0.9 \times 7 \mathrm{~cm})$ of phosphocellulose (Whatman Inc. $\mathrm{P}-11)$. Samples were dissolved in $2 \mathrm{ml}$ of starting buffer (0.001 M sodium acetate, $\mathrm{pH}$ 3.8) and applied to the column equilibrated with the same buffer at $43^{\circ} \mathrm{C}$. Peptides were then eluted with a linear gradient of $\mathrm{NaCl}$ from 0 to $0.1 \mathrm{M}$ over a total volume of $600 \mathrm{ml}$.

Molecular sieve chromatography. Separation and molecular weight determination of denatured collagen chains and $\mathrm{CNBr}$ peptides were achieved on calibrated columns $(2 \times$ $120 \mathrm{~cm})$ of agarose beads, A $15 \mathrm{~m}$ or A $1.5 \mathrm{~m}(200-400 \mathrm{mesh}$, Bio-Rad Laboratories), or Sephadex G-50 SF (Pharmacia Fine Chemicals, Inc.) in $0.05 \mathrm{M}$ Tris/1 M CaCl, $\mathrm{pH} 7.4$, at room temperature as described previously (25). All samples were heated to $43^{\circ} \mathrm{C}$ to ensure denaturation before application to the column. A drop of tritiated water was added to each sample to mark the column volumes (25).

Amino acid and carbohydrate analyses. For amino acid analysis, samples were hydrolyzed in doubly distilled constant boiling $\mathrm{HCl}$ under an atmosphere of nitrogen for $24 \mathrm{~h}$ at $110^{\circ} \mathrm{C}$. Analyses were performed on an automatic analyzer (Beckman Instruments, Inc., Spinco Div., Palo Alto, Calif., model 121) using a four-buffer elution system previously described (26).

Samples for analysis of hydroxylysine glycosides were hydrolyzed in $2 \mathrm{~N} \mathrm{NaOH}$ in borosilicate-free test tubes at $110^{\circ} \mathrm{C}$ for $24 \mathrm{~h}$. Analyses were performed on a Beckman 121 analyzer employing the methods described by Askenasi and Kefalides (27).

\section{RESULTS}

Attempts to extract native collagen directly from normal or fibrotic lungs using $1 \mathrm{M} \mathrm{NaCl}$ or $0.5 \mathrm{M}$ acetic acid were unsuccessful due to extremely low yields. Much greater quantities of collagen, however, could be ex- tracted by limited digestion with pepsin. The results are presented in Table I. Generally, the first pepsin extract contained lower yields of solubilized collagen than the second and third extracts. The yields of collagen from pepsin-digested fibrotic lung were higher than for normal lungs (Table I).

After purification of the pepsin-extracted collagen by dialysis against $0.01 \mathrm{M} \mathrm{Na}_{2} \mathrm{HPO}_{4}$, and $\mathrm{NaCl}_{\text {precipitation }}$ from acetic acid solution, the collagen fraction precipitating at $1.5 \mathrm{M} \mathrm{NaCl}$ at $\mathrm{pH} 7.4$ was chromatographed on CM-cellulose. The elution pattern obtained from fibrotic lungs is shown in Fig. 1. The peaks were identified by their behavior during agarose chromatography (not shown) and amino acid analysis (Table II). The peak labeled $\alpha 1$ (III) (Fig. 1), eluted from agarose A $15 \mathrm{~m}$ as a homogenous peak at the position corresponding to the $\gamma$-component (mol wt 280,000). Thus, the predominant species of collagen in the $1.5 \mathrm{M} \mathrm{NaCl}$ precipitate was type III.

The pepsin-extracted collagen fraction precipitating at the $\mathrm{NaCl}$ concentration between 1.5 and $2.5 \mathrm{M}$ at $\mathrm{pH} 7.4$ was also fractionated on CM-cellulose. A representative chromatogram is illustrated again in Fig. 1. The peak labeled $\alpha 1$ (I) was identified by its elution position on agarose A $15 \mathrm{~m}$ chromatography (figure not shown, mol wt 95,000), amino acid analysis (Table II), and chromatography of a $\mathrm{CNBr}$ digest (see below). Significant amounts of the type III chains were also present in the $2.5 \mathrm{M} \mathrm{NaCl}$ precipitate, reflecting incomplete precipitation of type III collagen at $1.5 \mathrm{M} \mathrm{NaCl}$ (14). However, gel filtration on agarose A $15 \mathrm{~m}$ allowed clear-cut separation and purification of [ $\alpha 1$ (III)], (mol wt 280,000) and $\alpha 2$ ( $\mathrm{mol}$ wt 95,000). Amino acid analysis (Table II) and chromatography of $\mathrm{CNBr}$ digests of these materials (see below) confirmed their

TABLE I

Relative Amounts of Collagen and Protein Extracted* from Normal and Fibrotic Human Lung

\begin{tabular}{|c|c|c|c|c|}
\hline \multirow[b]{2}{*}{ Extractants } & \multicolumn{2}{|c|}{ Normal } & \multicolumn{2}{|c|}{ Fibrotic } \\
\hline & Collagent & Protein§ & Collagen $\ddagger$ & Protein£ \\
\hline $0.05 \mathrm{M}$ Tris $\mathrm{HCl}, \mathrm{pH} 7.4$ & $\mathbf{0}$ & 6.3 & $\mathbf{0}$ & 8.9 \\
\hline First pepsin digestion & 4.1 & 13.0 & 7.2 & 16.9 \\
\hline Second pepsin digestion & 7.2 & 7.1 & 18.8 & 12.3 \\
\hline Third pepsin digestion & 4.8 & 4.7 & 8.7 & 6.1 \\
\hline Total extracted & 16.1 & 31.1 & 34.7 & 44.2 \\
\hline
\end{tabular}

* The results are expressed as percent of collagen or protein solubilized by each extractant.

‡ Collagen content based on hydroxyproline analysis.

$\S$ Total protein content was determined from amino acid analysis of a portion of each extract and converted to protein assuming a mean residue weight of 100 . 


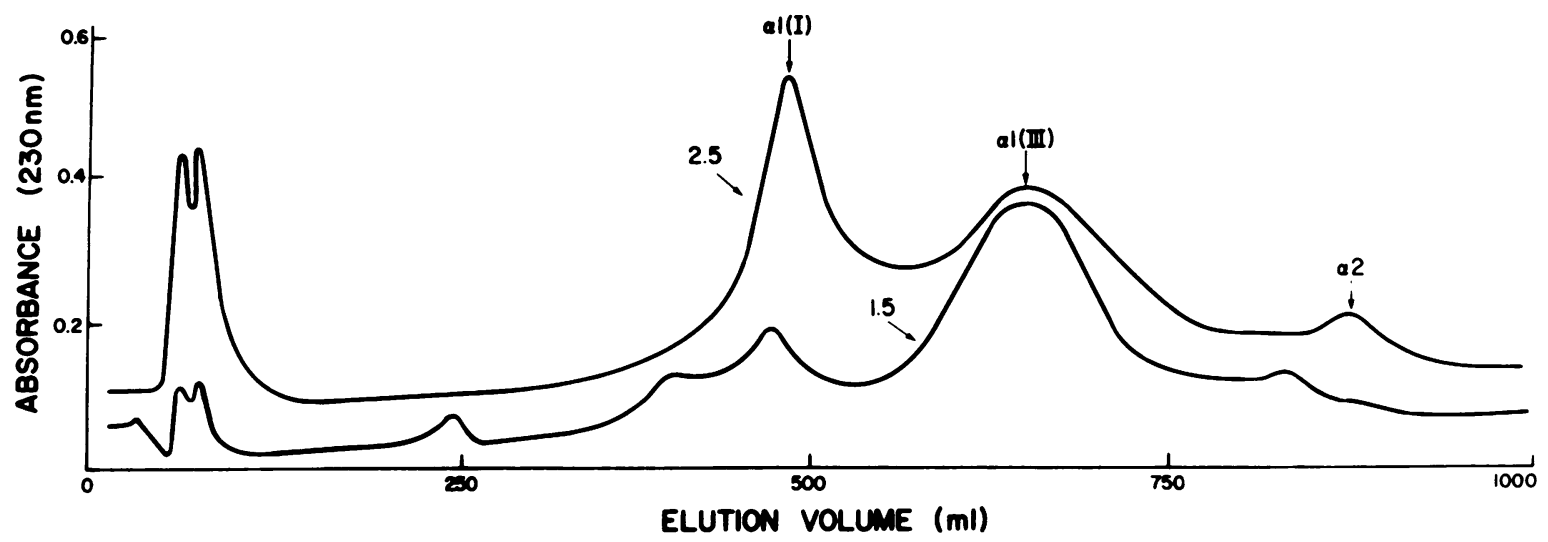

FIGURE 1 CM-cellulose chromatography of pepsin-solubilized human lung collagen. The lower curve represents the elution pattern obtained from the fraction precipitating at $1.5 \mathrm{M} \mathrm{NaCl}$ at $\mathrm{pH} 7.4$ (indicated by an arrow), and the upper curve, the fraction precipitating between 1.5$2.5 \mathrm{M} \mathrm{NaCl}$ (indicated by an arrow). The peaks were identified by their behavior during agarose A $15 \mathrm{~m}$ chromatography and subsequent analyses of their amino acid compositions and the $\mathrm{CNBr}$ peptides. The presence of the $\alpha 1$ (III) chains in the 1.5-2.5 NaCl precipitate (upper curve) is due to incomplete precipitation of type III at $1.5 \mathrm{M} \mathrm{NaCl}$.

TABLE II

Amino Acid Composition of Human Lung Collagens;* Values Expressed as Amino Acid Residues per 1,000 Amino Acids

\begin{tabular}{|c|c|c|c|c|c|c|}
\hline \multirow[b]{2}{*}{ Amino acid } & \multicolumn{3}{|c|}{ Normal } & \multicolumn{3}{|c|}{ Fibrotic } \\
\hline & $\alpha 1(\mathrm{I})$ & $\alpha 2$ & $\alpha 1($ III) & $\alpha 1(\mathrm{I})$ & $\alpha 2$ & $\alpha 1$ (III) \\
\hline 4-Hydroxyproline & 107 & 103 & 118 & 108 & 98 & 114 \\
\hline Aspartic acid & 45 & 44 & 46 & 44 & 43 & 49 \\
\hline Threonine & 17 & 18 & 16 & 18 & 16 & 15 \\
\hline Serine & 31 & 30 & 34 & 32 & 28 & 36 \\
\hline Glutamic Acid & 78 & 74 & 72 & 74 & 72 & 73 \\
\hline Proline & 116 & 111 & 109 & 122 & 114 & 106 \\
\hline Glycine & 335 & 340 & 349 & 333 & 346 & 350 \\
\hline Alanine & 108 & 96 & 93 & 112 & 100 & 96 \\
\hline Cysteineł & $\mathbf{0}$ & $\mathbf{0}$ & 2.1 & 0 & 0 & 3.1 \\
\hline Valine & 21 & 28 & 17 & 20 & 31 & 17 \\
\hline Methionine§ & 7.2 & 4.9 & 8.2 & 7.3 & 3.1 & 8.3 \\
\hline Isoleucine & 10 & 16 & 14 & 8.8 & 18 & 15 \\
\hline Leucine & 22 & 30 & 24 & 21 & 32 & 24 \\
\hline Tyrosine & 1.1 & 3.3 & 2.8 & 1.4 & 2.4 & 3.2 \\
\hline Phenylalanine & 10 & 8.6 & 9.2 & 9.3 & 10.0 & 9.1 \\
\hline Hydroxylysine & 10.0 & 10.4 & 11.1 & 7.1 & 11.1 & 8.3 \\
\hline Lysine & 27.0 & 20.7 & 24.2 & 28.0 & 19.5 & 24.3 \\
\hline Histidine & 3.7 & 10 & 6.2 & 3.9 & 8.8 & 6.1 \\
\hline Arginine & 48 & 47 & 46 & 50 & 48 & 46 \\
\hline Glc-Gal-Hyl\| & 0.85 & & 0.83 & 0.77 & & 0.72 \\
\hline Gal-Hyl\| & 0.12 & & 0.35 & 0.25 & & 0.24 \\
\hline
\end{tabular}

* Average of three analyses each.

† Calculated as cysteic acid.

$\$$ Includes methionine sulfone.

|| Analysis performed after $2 \mathrm{~N} \mathrm{NaOH}$ hydrolysis. Expressed as residue per 1,000 amino acids. 


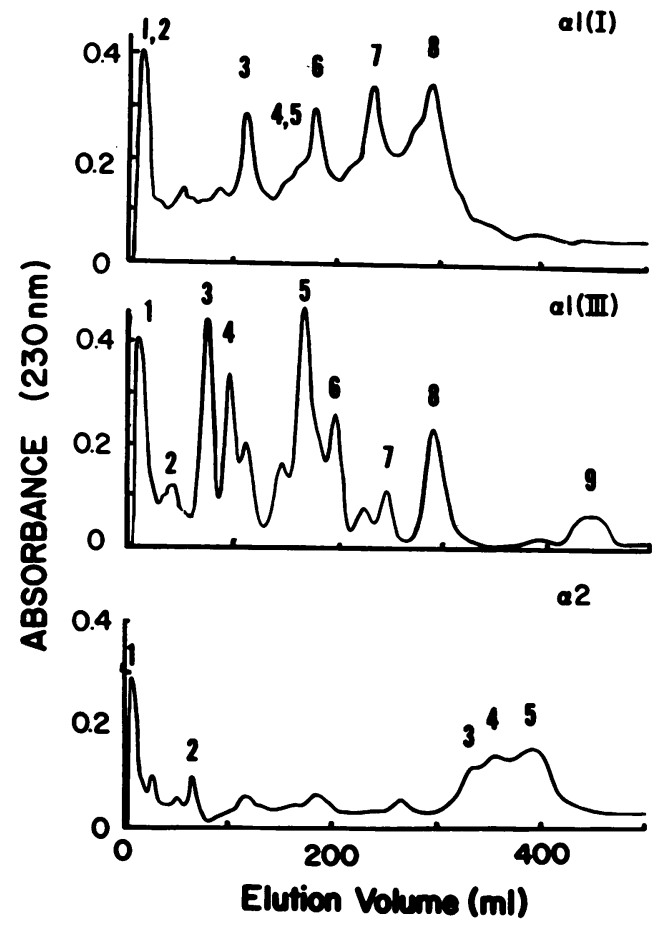

Figure 2 CM-cellulose elution patterns of $\mathrm{CNBr}$ digests of human lung $\alpha 1$ (I), $\alpha 1$ (III), and $\alpha 2$. Chromatography was performed under identical conditions of column size, elution gradient, flow rate, and recorder chart speed (see Methods). The peaks were identified by their behavior during subsequent ion exchange and (or) molecular sieve chromatography and amino acid analyses.

identity. No peaks corresponding to $\beta_{11}$ or $\beta_{12}$ were observed on gel filtration.

The amino acid composition and the carbohydrate content of the $\alpha$-chains isolated from normal and fibrotic lungs are listed in Table II. The values obtained for normal and fibrotic collagens, both type I and type III, are identical within experimental error except possibly for the degree of lysine hydroxylation. The content of hydroxylysine was consistently observed to be lower in the $\alpha 1$ (I) and the $\alpha 1$ (III) chains isolated from the diseased lungs than that obtained from normal lungs (Table II). The composition obtained for the lung collagen chains in the present study is also in agreement with the composition reported previously for type I and type III collagens of human skin $(14,28)$ aorta $(12,13)$ and leiomyoma (12), except that the lung collagens contain elevated amounts of hydroxlysine.

To further characterize the covalent structure of type III collagen of lung, the $\alpha 1$ (III) chain obtained by CMcellulose and agarose chromatography was cleaved at the methionyl residues by treatment with $\mathrm{CNBr}$, and the resulting peptides were fractionated on $\mathrm{CM}$-cellulose at $\mathrm{pH} 3.8$ (Fig. 2). Each of the peptides was further purified as outlined below. Peptides 1 and 2 were rechromatographed on phosphocellulose and molecular weights determined by Sephadex G-50 SF gel filtration. Sephadex G-50 SF likewise was used for isolation and molecular weight determination of peptides 3,6 , and 7 . The larger peptides 4,5 , and 8 were further purified by rechromatography on CM-cellulose at $\mathrm{pH} 4.8$ (24). Their molecular weights were determined on agarose A $1.5 \mathrm{~m}(25)$. Peptide 9 could only partially be eluted by the gradient used. Application of $1 \mathrm{M} \mathrm{NaCl}$ solution, however, removed the bulk of the peptide. On agarose A $1.5 \mathrm{~m}$ gel filtration, peptide 9 eluted as two peaks; one with a mol wt of 23,000 and the other with a mol wt of 45,000. Both, however, had an identical amino acid composition. Since the peptide contains a residue of cysteine, presumably the larger peptide represents a dimer of the peptide linked together through a disulfide bridge. A similar polymerization of the peptide was noted by Chung et al. (29) in the $\mathrm{CNBr}$ peptides from uterine leiomyoma. The amino acid composition and molecular weight of the purified $\mathrm{CNBr}$ peptides are presented in Table III. The sum of the composition of the peptides agree within experimental error, with the observed composition of $\alpha 1$ (III). The data are also in agreement with the values obtained on the $\mathrm{CNBr}$ peptides of uterine leiomyoma (29).

The lung $\alpha 1(\mathrm{I})$ and $\alpha 2$ chains were also further characterized by cyanogen bromide digestion, and separation of the resulting peptides by CM-cellulose chromatography and agarose A $1.5 \mathrm{~m}$ gel filtration. The elution patterns from CM-cellulose chromatography are shown for comparison in Fig. 2. Each of the peptides was further purified by the procedures described for the $\alpha 1$ (III) peptides. No differences were noted from the results obtained from analyses of human skin $\alpha 1(\mathrm{I})$ and $\alpha 2$ with respect to molecular weights and amino acid composition (data not shown) (30).

Next, the question of collagen polymorphism in normal and fibrotic lungs was investigated. Because of the fact that pepsin solubilization yielded relatively small portions of the total collagen present in the lung, determination of the $\alpha 1(\mathrm{I}): \alpha 1$ (III) ratio in the extracted collagen would not have reflected their distribution in the tissue. Thus, the washed total lung homogenates were subjected to $\mathrm{CNBr}$ digestion directly. Prior extraction of the

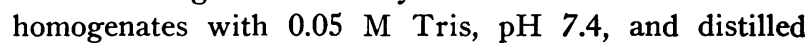
water was essential to remove large quantities of noncollagenous proteins and other substances. Under the experimental conditions used in the present study, $88 \%$ or more of the total hydroxyproline was solubilized by $\mathrm{CNBr}$ digestion. $\mathrm{CNBr}$ digests were then fractionated on CM-cellulose. As shown in Fig. 3, the chromatographic pattern was complex due to the presence of peptides from both type I and type III collagens, with the 
TABLE III

Amino Acid Composition* and Molecular Weight of CNBr Peptides from Human Lung $\alpha 1$ (III)

\begin{tabular}{|c|c|c|c|c|c|c|c|c|c|c|c|}
\hline Amino acid & 1 & 2 & 3 & 4 & 5 & 6 & 7 & 8 & 9 & Total & $\alpha 1($ III $) \ddagger$ \\
\hline 4-Hydroxyproline & $2(1.8)$ & $7(7.1)$ & 12 & 19 & 30 & 11 & $3(3.0)$ & 15 & 30 & 129 & 116 \\
\hline Aspartic Acid & $0(0.5)$ & $1(1.3)$ & $2(2.1)$ & $9(9.1)$ & $9(8.9)$ & $4(3.5)$ & $4(4.1)$ & $7(7.2)$ & 10 & 46 & 50 \\
\hline Threonine & $0(0.2)$ & $\mathbf{0}$ & $1(1.3)$ & $5(4.7)$ & $3(2.9)$ & $1(1.4)$ & $1(1.3)$ & 0 & $4(4.3)$ & 15 & 16 \\
\hline Serine & $0(0.5)$ & $3(3.4)$ & $4(4.6)$ & $0(0.3)$ & $9(8.9)$ & $3(3.2)$ & $0(0.4)$ & $1(1.4)$ & 13 & 33 & 35 \\
\hline Glutamic Acid & $1(0.9)$ & $3(3.4)$ & $7(6.7)$ & $10(9.9)$ & 16 & $6(6.0)$ & $5(4.8)$ & 11 & 15 & 74 & 75 \\
\hline Proline & $1(1.1)$ & $5(5.3)$ & 13 & 17 & 26 & $9(8.7)$ & $2(2.2)$ & 10 & 23 & 106 & 100 \\
\hline Glycine & $4(4.3)$ & 17 & 31 & 60 & 81 & 31 & 15 & 49 & 77 & 365 & 364 \\
\hline Alanine & $1(1.0)$ & $1(1.4)$ & $7(6.9)$ & 15 & 19 & $7(7.0)$ & $2(2.1)$ & 19 & 19 & 90 & 90 \\
\hline Cysteine 8 & 0 & 0 & 0 & $\mathbf{0}$ & 0 & 0 & $\mathbf{0}$ & $\mathbf{0}$ & $2(1.6)$ & 2 & 2 \\
\hline Valine & 0 & $1(1.0)$ & $1(0.6)$ & $\mathbf{0}$ & $5(5.2)$ & $2(1.6)$ & $\mathbf{0}$ & $2(2.0)$ & $5(5.3)$ & 16 & 17 \\
\hline Methionine & 0 & 0 & 0 & 0 & 0 & 0 & $\mathbf{0}$ & 0 & 0 & $\mathbf{0}$ & 7 \\
\hline Isoleucine & $\mathbf{0}$ & o & $3(2.6)$ & 0 & $4(3.6)$ & $2(1.6)$ & 0 & $2(1.9)$ & $3(2.7)$ & 14 & 15 \\
\hline Leucine & 0 & o & $2(2.0)$ & $6(5.7)$ & $6(5.7)$ & $2(1.6)$ & $2(2.4)$ & $2(2.0)$ & $4(4.4)$ & 24 & 24 \\
\hline Tyrosine & $\mathbf{0}$ & o & $2(1.5)$ & 0 & 0 & 0 & 0 & 0 & 0 & 2 & 2 \\
\hline Phenylalanine & $\mathbf{0}$ & 0 & $1(1.1)$ & $0(0.3)$ & $3(2.6)$ & $1(0.6)$ & $1(0.9)$ & $1(0.9)$ & $1(1.2)$ & 8 & 8 \\
\hline Hydroxylysine & $\mathbf{0}$ & 0 & $1(0.7)$ & $1(0.6)$ & $1(0.8)$ & $1(0.6)$ & $2(2.1)$ & $1(0.7)$ & $1(1.2)$ & 7 & 9 \\
\hline Lysine & $0(0.4)$ & $1(1.2)$ & $2(1.7)$ & $6(6.3)$ & $8(7.9)$ & $2(2.2)$ & $1(0.9)$ & $4(4.4)$ & $4(4.1)$ & 29 & 26 \\
\hline Histidine & 0 & 0 & 1 (1.4) & 0 & 0 & 0 & 0 & 0 & $3(3.2)$ & 4 & 7 \\
\hline Arginine & $0(0.4)$ & $2(2.2)$ & $4(3.5)$ & $3(3.2)$ & $7(7.3)$ & $4(4.3)$ & $2(2.3)$ & $9(9.0)$ & 11 & 42 & 47 \\
\hline Homoserine\| & 1 & 1 & 1 & 1 & 1 & 1 & 1 & 1 & 1 & 9 & 0 \\
\hline $\begin{array}{l}\text { Total } \\
\text { Molecular Weight }\end{array}$ & ${ }_{1,200}^{10}$ & $\begin{array}{l}40 \\
4,000\end{array}$ & $\begin{array}{l}91 \\
9,000\end{array}$ & $\begin{array}{l}152 \\
13,500\end{array}$ & $\begin{array}{l}228 \\
22,000\end{array}$ & $\begin{array}{l}87 \\
8,000\end{array}$ & $\begin{array}{l}41 \\
4,000\end{array}$ & $\begin{array}{l}134 \\
12,000\end{array}$ & $\begin{array}{l}227 \\
23,000\end{array}$ & $\begin{array}{l}997 \\
96,700\end{array}$ & 1,012 \\
\hline
\end{tabular}

- Residues per peptide rounded off to the nearest whole number. Actual values are given where less than 10 residues occur.

$\uparrow$ Calculated from $\alpha 1$ (III) amino acid analyses using an average residue mol wt of 91.2 and assuming a mol wt of 92.400 for $\alpha 1$ (III) when obtained after solubilization with pepsin.

Determined as cysteic acid after reduction of peptide 9.

|| Includes homoserine lactone.

Teptides 1, 2, 3, 6, and 7 were analyzed on Sephadex G-50 SF, and 4, 5, 8 and 9 on Agarose A 1.5m (25).

characteristic pattern of type I being more evident. The presence of peptide 4 of $\alpha 1$ (III) preceding $\alpha 1$ (I)-CB3 was a useful qualitative indicator for type III collagen. For quantitative purposes, however, peptide 8 of type III collagen coeluted with $\alpha 1$ (I)-CB8 and $\alpha 1$ (I)-CB(8-3), and because of the difference in their molecular weight, these peptides could be separated by agarose A $1.5 \mathrm{~m}$ chromatography (Fig. 4). Three peaks were consistently seen. The first eluted at a position corresponding to a mol wt of 37,000 and was identified as uncleaved $\alpha 1$ (I)-CB (8-3) (22). This was generally present as the shoulder on the next major peak identified as $\alpha 1$ (I)-CB8 with a mol wt of 24,000 . The uncleaved $\alpha 1$ (I) $-\mathrm{CB}(8-3)$ usually represented $10-15 \%$ of the total $\alpha 1$ (I)-CB8 and was added to it to obtain quantitation of type I collagen. The last peak eluting at a position corresponding to a mol wt of 12,000 was identified as peptide 8 of type III collagen by amino acid analysis. The molar ratio of type I and type III collagens present in lung was then calculated from the moler ratio of $\alpha 1$ (I)-CB8 plus $\alpha 1(\mathrm{I})-\mathrm{CB}(8-3)$ and peptide 8 of type III. Quantitation was based on the hydroxyproline assay of each of the peaks. Table IV summarizes the relative abundance of each collagen type in three normal and five fibrotic lungs. Significantly lower levels of type III collagen were consistently observed in the diseased lung.
To assess the reliability and the reproductibility of these determinations under our conditions, several experiment were performed:

(a) Known amounts of purified $\alpha 1$ (I) and $\alpha 1$ (III) (CM-cellulose and agarose chromatography) were mixed to yield standard mixtures containing 10, 20,30, and $40 \% \alpha 1$ (III), and each mixture was separately digested with $\mathrm{CNBr}$, and the resulting peptides were separated by CM-cellulose chromatography. A pattern obtained from a mixture consisting of $30 \%$ type III and $70 \%$ type $I$ is shown in Fig. 3 . The material indicated

\section{TABLE IV}

Percentage of Type III Collagen in Normal and Fibrotic Human Lung; Values Expressed as Percent Type III Collagen with Respect to Type I

\begin{tabular}{ll}
\hline Normal lung* & Fibrotic lung* \\
\hline $31 \pm 2(3)$ & $20 \pm 2(3)$ \\
$33(1)$ & $15 \pm 3(3)$ \\
$28(1)$ & $18(1)$ \\
& $12(1)$ \\
& $24(1)$
\end{tabular}

* Each value represents an individual lung. Numbers in parentheses indicate the number of times each sample was analyzed starting from the whole lung. The variation from the average value is indicated by \pm designation. 


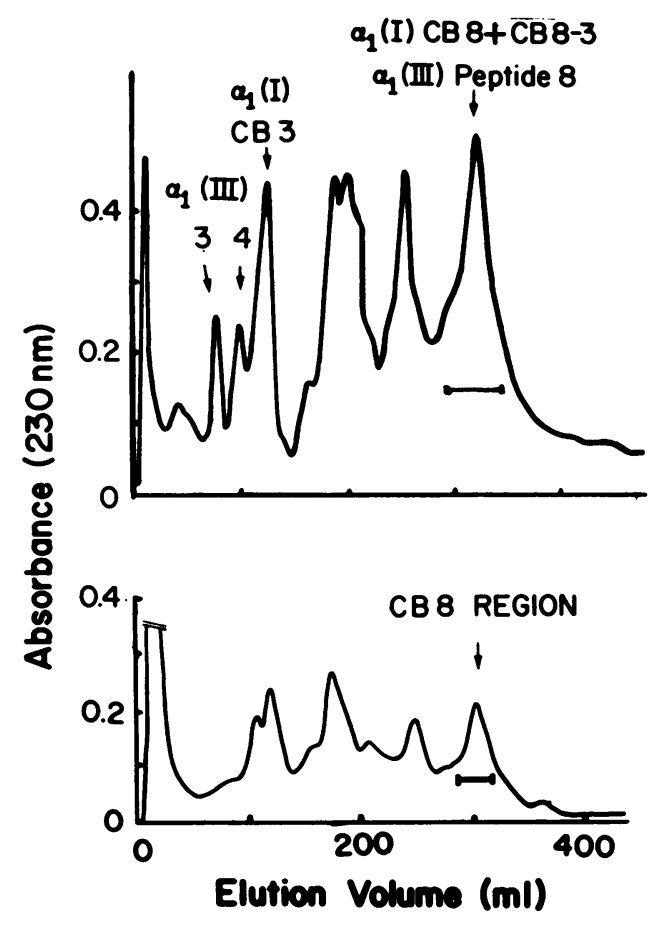

FIGURE 3 CM-cellulose chromatography of a $\mathrm{CNBr}$ digest of washed fibrotic lung residue (lower panel) and of a standard mixture consisting of $70 \%$ purified $\alpha 1(\mathrm{I})$ and $30 \%$ purified $\alpha 1$ (III) (upper panel). The fractions indicated by the bar (-) were pooled, desalted on Sephadex G-25, lyophilized, and subjected to agarose A $1.5 \mathrm{~m}$ chromatography.

by the horizontal bar was collected and after desalting and lyophilization, subjected to gel filtration on agarose A $1.5 \mathrm{~m}$ (Fig. 4). The percent of type III calculated from hydroxyproline analyses of the resulting peptide fractions was $28 \%$. By identical maneuvers, values of 37,22 , and $9 \% \alpha 1$ (III) were obtained from the mixtures containing 40,20 , and $10 \%$ type III, respectively.

(b) Standard mixtures of purified $[\alpha 1 \text { (III) }]_{3}$ and type I collagen $[\alpha 1(\mathrm{I})]_{2} \alpha 2$ were made by mixing known amounts of each, and analyzed by identical procedures described above. Quantitation of the mixtures containing 40,30 , and $20 \%[\alpha 1(\text { III })]_{3}$ yielded corresponding values of 38,30 , and $21 \%$, respectively.

(c) Triplicate lung samples were taken from each of the following: one normal and two different patients. Each sample was separately digested with $\mathrm{CNBr}$. The resulting peptides were separated by $\mathrm{CM}$-cellulose and agarose chromatography in a manner described above. The percent of type III present in the triplicate samples agreed within 3 percentage points as indicated in Table IV.

\section{DISCUSSION}

Histopathologic studies indicate that the collagen content of human lung increases in chronic pulmonary fibrosis
(17). The chemical nature of collagen in lung has never been fully investigated and represents the aim of this investigation. Type I and type III collagens which are present in peripheral lung were made soluble by limited pepsin digestion under conditions which maintain the helical conformation of the molecule. Pepsin, under these conditions, cleaves only the nonhelical terminal segments which contain the lysine-derived interchain cross-links $(31,32)$. The bulk of the collagen molecule is resistant to pepsin digestion so long as the native triple helix remains intact. Pepsin treatment of the total tissue, therefore, has been used to solubilize collagen with similar physical-chemical properties as the intact tropocollagen molecule.

The preservation of the triple helical structure enables extracted lung collagens to be purified by low salt precipitation (0.01 M Na $\mathrm{HPO}_{4}$ ), acid precipitation ( $0.5 \mathrm{M}$ acetic acid with $1 \mathrm{M} \mathrm{NaCl}$ ), and finally selective precipitation of types III and I collagens at 1.5 and $2.5 \mathrm{M}$ $\mathrm{NaCl}$ (0.05 M Tris, $\mathrm{pH} 7.4$ ), respectively. CM-cellulose chromatography of both the 1.5 and $2.5 \mathrm{M} \mathrm{NaCl}$ precipitates indicates that quantitative separation of the two types of collagen was not achieved, with a considerable amount of type III remaining in the $1.5-2.5 \mathrm{M} \mathrm{NaCl}$ fraction. Nevertheless, homogeneous $\alpha 1(\mathrm{I}), \alpha 2$, and $\alpha 1$ (III) chains could be obtained by further fractionation of the CM-cellulose fractions on agarose. The reason the observed $\alpha 1(\mathrm{I}): \alpha 2$ ratio being greater than $2: 1$ is not clear. A possible explanation might be greater susceptibility of the $\alpha 2$ chain to peptic digestion with a corresponding apparent increase in the $\alpha 1(\mathrm{I}): \alpha 2$ ratio.

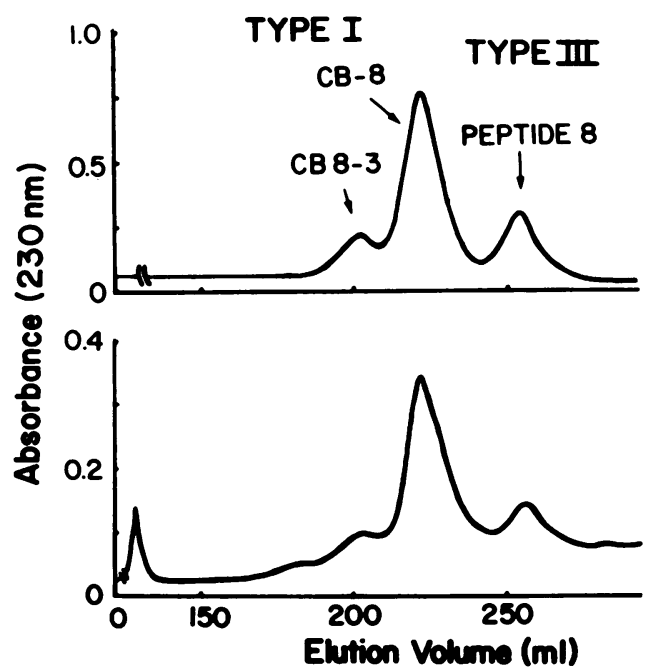

Figure 4 Agarose A $1.5 \mathrm{~m}$ gel filtration of the fractions collected from CM-cellulose chromatography (Fig. 3). Lower panel, fibrotic human lung. Upper panel, standard mixture of $70 \% \alpha 1$ (I) and $30 \% \alpha 1$ (III). 
The possibility must also be considered that $\alpha 1(\mathrm{I})$ may be contaminated with $\alpha 1$ (II) from the remaining small bronchial tree or $\alpha 1$ (IV) from the remaining vasculature. Both of these might have been solubilized by pepsin digestion and eluted from CM-cellulose in a position similar to $\alpha 1$ (I) $(15,33)$. The relatively high levels of hydroxylysine observed in this study might also be consistent with this supposition. The presence of significant amounts of type II collagen may, however, be ruled out from the following considerations. Human $\alpha 1$ (II) contains 14 residues $/ 1,000$ of hydroxylysine (34). This would necessitate a large amount of contamination to account for the high level of the amino acid found in human lung $\alpha 1(\mathrm{I})$. At that level of contamination, the $\alpha 1$ (II) specific $\mathrm{CNBr}$ peptides would have been detected during isolation of the $\alpha 1$ (I) peptides. No such peptides were detected in the $\mathrm{CNBr}$ digests of lung $\alpha 1$ (I).

Type IV collagen has not been characterized as well as the other types. However, available data indicate that it is distinguished by its high content of 3-hydroxyproline and carbohydrate $(15,16)$. The lung $\alpha 1(\mathrm{I})$ in the present paper contained only about one residue each of 3-hydroxyproline and hydroxylysineglycosides, and thus a significant contamination by $\alpha 1$ (IV) is unlikely.

The amino acid composition of the lung $\alpha$-chains revealed no significant differences between the normal and fibrotic lung collagen except for a possible decrease in lysine hydroxylations (Table II) in the diseased organ. The observed values for hydroxylysine are 7.1 and 8.3 for $\alpha 1$ (I) and $\alpha 1$ (III) of the pathologic organ as compared with 10.0 and 11.1 for $\alpha 1$ (I) and $\alpha 1$ (III) of normal organ, respectively. These values should be interpreted with some caution, since slight variations were also observed in the total lysine content (lysine plus hydroxylysine) of various chains. The magnitude of the decrease in hydroxylysine, however, appears to be greater than accountable by variations in the measurement.

Proline hydroxylation was not altered in the diseased organ. This is interesting in view of the fact that the posttranslational enzymes, i.e., prolyl and lysyl hydroxylases have been shown to increase during experimentally induced fibrosis (35). The fact that there is no increase in hydroxyproline or hydroxylysine content suggests that these increased enzymatic activities reflect an overall increased collagen synthesis incident to the fibrotic process. The levels of hydroxylysine in both normal and fibrotic lungs are higher when compared to human skin where the hydroxylysine content has been reported to be 5 or $6 / 1,000$ residues $(14,29)$. This must, therefore, represent a tissue-specific increase in lysine hydroxylation. The functional significance of this amino acid in collagen is not understood at the present time. The occurrence of tissue-specific differences in the content of hydroxylysine, and its alterations in certain diseased states, such as rickets (36), however, do suggest its involvement in some aspect of collagen function.

Glycosylation of both fibrotic and normal lung collagen, types I and III, was found to be identical. $\alpha 1$ (I) contained approximately 0.8 residue of O-glucosylgalactosylhydroxylysine and 0.3 residue of $\mathrm{O}$-galactosylhydroxylysine per chain. Type III collagen contained approximately the same amount. No correction factors were used to account for partial destruction due to hydrolysis. The lack of change in the degree of glycosylation of hydroxylysine in chronic pulmonary fibrosis is at variance with the data obtained from scarred rabbit cornea in which substantial decreases in glycosylation were noted in the scar tissue as compared to the control (37). That data, however, was obtained from collagenase digests of total tissue, rather than from purified collagen, and must therefore be regarded with a certain degree of uncertainty.

The CNBr peptides from lung $\alpha 1(\mathrm{I}), \alpha 2$, and $\alpha 1$ (III) were isolated and characterized with respect to molecular weight and amino acid composition. Nine peptides were obtained from $\mathrm{CNBr}$ digestion of type III human lung collagen, and were purified by a combination of ion exchange and molecular sieve chromatography. The amino acid compositions were in agreement with those obtained from human skin (29), with the exception of peptides 1,3 , and 6 . In the present study no leucine or isoleucine was found in peptide 1 , while one each of the amino acids was previously found (29). Whether these differences represent tissue-specific variations is not known. Peptide 3 contained 91 amino acids as opposed to 109 which was previously reported for skin (29). Although the sequence of these $\mathrm{CNBr}$ peptides within the $\alpha$-chain has not been established, peptide 3 most likely represents the amino terminus since two tyrosine residues are present. In type I collagen, tyrosine is present only in the amino or carboxy terminal peptide. Variable pepsin digestion would have therefore yielded discrepancies in the length of this peptide and explain the difference. The partial amino acid sequence of peptides 4,5 , and 6 has already established their analogy with CB3, CB7, and CB8 of $\alpha 1$ (I) polypeptide chain (38). Peptide 9 contained the two cysteine residues. It was isolated as a monomer and dimer with mol wt of 23,000 and 45,000 , respectively, with the same amino acid composition. This peptide was reported to be the carboxy terminal peptide, and therefore analogous to $\alpha 1$ (I)-CB6. The position of peptides $1,2,7$, and 8 in relation to $\alpha 1$ (I) chain has not yet been determined. No significant differences were observed in the $\mathrm{CNBr}$ 
peptides of human lung $\alpha 1$ (I) and $\alpha 2$ as compared to those of corresponding human skin chains (30).

The specific nature of the $\mathrm{CNBr}$ cleavage and the resulting peptides allowed investigation of collagen polymorphism in normal and diseased lung. Peptide 8 of type III collagen coeluted from CM-cellulose with $\alpha 1$ (I)CB8 and the partially cleavaged $C B(8-3)$. Since the latter peptides are larger in mol wt $(24,000$ and 37,000 , respectively) as opposed to peptide 8 of $\alpha 1$ (III), they were readily separated by agarose A $1.5 \mathrm{~m}$ chromatography. Because of the reproducible elution pattern in this area of the CM-cellulose chromatogram, no difficulties were encountered in identifying and pooling consistant fractions, even in $\mathrm{CNBr}$ digests of the total tissue. Since quantitation was based on hydroxyproline assay, possible contamination by noncollagenous proteins would not have produced errors. In reality, however, quantitation by planimetry of the area under the chromatographic peaks yielded nearly identical results. The reproducibility of the procedures used in this study was supported by experiments using artificial mixtures of purified type I and type III collagens as well as by good agreement obtained in triplicate analyses of several lung samples (Table IV).

Normal lung contained an average of $31 \%$ type III collagen. Variable results were obtained from fibrotic lungs, depending on the patient, with a range of $12-24 \%$ type III collagen. This is presumably related to the varying severity among different patients, but no attempt was made to quantitatively correlate the biochemical findings with histopathologic findings. The consistant depression in type III collagen indicates that the fibrotic response of this tissue to injury, whatever it may be in chronic pulmonary fibrosis, is to result in a relative increase in the amount of type I in relation to type III collagen. Whether this is due to a preferential increase in the synthesis of type I collagen or due to a preferential increase in the degradation of type III collagen, or both, cannot be decided at present.

An additional possibility must also be considered that the relative diminution in the content of type III may be a result of a reduction in the relative amount of blood vessels in the diseased lung and not due to any changes in the collagen composition of lung scar per se. It was previously reported that blood vessels are relatively rich in type III collagen (13). To our knowledge, there have been no studies designed to quantitate the blood vessel content of lung in normal or diseased states. Microscopic examination of pathologic lung slides might suggest that the blood vessel content may be diminished. Our preliminary results obtained from studies of scleroderma lungs from one patient, however, suggest that such a possibility is less likely, at least as an entire explana- tion of the observed collagen distribution.' Although the scleroderma lungs showed much of the same pathologic features as the idiopathic fibrosis, the relative distribution of type I and III collagens was unaltered.

Thus, it is not yet possible to precisely relate the biochemical findings to specific anatomic or pathologic loci in lung. Nevertheless, the results obtained in the present investigation do define biochemical changes in collagen in this disorder and provide basis for further investigation.

\section{ACKNOWLEDGMENTS}

The authors are grateful to Dr. J. M. Young, of this hospital, for obtaining tissue samples and for valuable discussions. We also acknowledge the excellent technical help of C. Dickey, G. Randall, and T. Marshall.

This study was conducted under Veterans Administration Research Projects 4826-01 and 4826-02, and was supported in part by U. S. Public Health Service grant AM 16506.

${ }^{2}$ Seyer, J. M., and A. H. Kang. Unpublished observations.

\section{REFERENCES}

1. DeRueck, A. V. S., and R. Porter. 1967. Development of the Lung. Little, Brown and Co., Boston. 1-408.

2. Emery, J. L. 1969. The Anatomy of the Developing Lung. William Heinemann Medical Books Ltd., Lavenham Press Ltd., Suffolk, England. 1-223.

3. Low, F. N. 1971. Extracellular components of the pulmonary alveolar wall. Arch. Intern. Med. 127: 847-852.

4. Pierce, J. A., and R. V. Ebert. 1969. Fibrous network of the lung and its change with age. Thorax. 20: 469476.

5. Fitzpatrick, M., and V. D. Hospelhorn. 1965. Studies of human pulmonary connective tissue. II. Amino acid composition of residues following collagenase digestion of lung connective tissues. Am. Rev. Respir. Dis. 92: 792-800.

6. Bradley, K. H., S. D. McConnell, and R. G. Crystal. 1974. Lung collagen composition and synthesis. Characterization and changes with age. J. Biol. Chem. 249: 2674-2683.

7. Turino, G. M., and R. V. Lourenço. 1972. The connective tissue basis of pulmonary mechanics. In Pulmonary Emphysema and Proteolysis. C. Mittman, Editor. Academic Press Inc., New York. 509-526.

8. Stanley, N. N., R. Alper, E. L. Cunningham, N. S. Cherniack, and N. A. Kefalides. 1975. Effects of a molecular change in collagen on lung structure and mechanical function. J. Clin. Invest. 55: 1195-1201.

9. Gallop, P. M., O. O. Blumenfeld, and S. Seifter. 1972. Structure and metabolism of connective tissue proteins. Annu. Rev. Biochem. 41: 617-672.

10. Piez, K. A., E. A. Eigner, and M. S. Lewis. 1963. The chromatographic separation and amino acid composition of the subunits of several collagens. Biochemistry. 2: $58-66$.

11. Nold, J. G., A. H. Kang, and J. Gross. 1970. Collagen molecules: distribution of alpha chains. Science (Wash. D. C.). 70: 1096-1098.

12. Chung, E., and E. J. Miller. 1974. Collagen polymorphism: characterization of molecules with the chain 
composition $[\alpha 1 \text { (III) }]_{3}$ in human tissues. Science (Wash. D. C.). 183: 1200-1201.

13. Trelstad, R. L. 1974. Human aorta collagens: evidence for three distinct species. Biochem. Biophys. Res. Commun. $57:$ 717-725.

14. Epstein, E. H., Jr. 1974. [ $\alpha 1$ (III) ] 3 human skin collagen. Release by pepsin digestion and preponderance in fetal life. J. Biol. Chem. 249: 3225-3231.

15. Kefalides, N. A. 1971. Isolation of a collagen from basement membranes containing three identical $\alpha$ chains. Biochem. Biophys. Res. Commun. 45: 226-234.

16. Kefalides, N. A. 1972. Isolation and characterization of cyanogen bromide peptides from basement membrane collagen. Biochem. Biophys. Res. Commun. 47: 11511158.

17. Spencer, H. 1967. Interstitial pneumonia. Annu. Rev. Med. 18 : 423-442.

18. Bradley, K., S. McConnell-Breul, and R. G. Crystal. 1975. Collagen in the human lung. Quantitation of rates of synthesis and partial characterization of composition. J. Clin. Invest. 55: 543-550.

19. Bradley, K., S. McConnell-Breul, and R. G. Crystal. 1974. Lung collagen heterogeneity. Proc. Natl. Acad. Sci. U. S. A. $71: 2828-2832$.

20. Bergman, I., and R. Loxley. 1963. Two improved simplified methods for the spectrophotometric determination of hydroxyproline. Anal. Chem. 35: 1961-1965.

21. Kang, A. H., K. A. Piez, and J. Gross. 1969. Characterization of the $\alpha$ chains of chick skin collagen and the nature of the $\mathrm{NH}_{2}$-terminal cross-link region. Biochemistry. 8: 3648-3655.

22. Kang, A. H., K. A. Piez, and J. Gross. 1969. Characterization of the cyanogen bromide peptides from the $\alpha 1$ chain of chick skin collagen. Biochemistry. 8: 15061514.

23. Bornstein, P., and K. A. Piez. 1965. Collagen: Structural studies based on the cleavage of methionyl bonds. Science (Wash. D. C.). 148: 1353-1355.

24. Butler, W. T., K. A. Peiz, and P. Bornstein. 1967. Isolation and characterization of the cyanogen bromide peptides from the $\alpha 1$ chain of rat skin collagen. Biochemistry. $6: 3771-3780$.

25. Piez, K. A. 1968. Molecular weight determination of random coil polypeptides from collagen by molecular sieve chromatography. Anal. Biochem. 26: 305-312.

26. Kang, A. H. 1972. Studies on the location of intermolecular cross-links in collagen. Isolation of a $\mathrm{CNBr}$ peptide containing $\delta$-hydroxylysinonorleucine. Biochemistry. $11: 1828-1835$.
27. Askenasi, R. S., and N. A. Kefalides. 1972. Simple chromatographic method for determination of ${ }^{14} \mathrm{C}$-labeled lysine, hydroxylysine, and hydroxylysine glycosides. Anal. Biochem. 47 : 67-72.

28. Bornstein, P., and K. A. Piez. 1964. A biochemical study of human skin collagen and the relation between intra- and intermolecular cross-linking. J. Clin. Invest. 43: 1813-1823.

29. Chung, E., E. M. Keele, and E. J. Miller. 1974. Isolation and characterization of the cyanogen bromide peptides from the $\alpha 1$ (III) chain of human collagen. Biochemistry. 13 : 3459-3464.

30. Epstein, E. H., Jr., R. D. Scott, E. J. Miller, and K. A. Piez. 1971. Isolation and characterization of the peptides derived from human and baboon skin collagen after cyanogen bromide cleavage. J. Biol. Chem. 246: 17181724

31. Drake, M. P., P. F. Davison, S. Bump, and F. O. Schmitt. 1966. Action of proteolytic enzymes on tropocollagen and insoluble collagen. Biochemistry. 5: 301312.

32. Bornstein, P., A. H. Kang, and K. A. Piez. 1966. The limited cleavage of native collagen with chymotrypsin, trypsin and cyanogen bromide. Biochemistry. 5: 38033812.

33. Trelstad, R. L., A. H. Kang, B. P. Toole, and J. Gross. 1972. Collagen heterogeneity. J. Biol. Chem. 240: 6469-6473.

34. Miller, E. J., and L. G. Lunde. 1973. Isolation and characterization of the cyanogen bromide peptides from the $\alpha 1$ (II) chain of bovine and human cartilage collagen. Biochemistry. 12: 3153-3159.

35. Risteli, J., and K. I. Kivirikko. 1974. Activities of prolyl hydroxylase, lysyl hydroxylase, collagen galactosyltransferase and collagen glucosyltransferase in the liver of rats with hepatic injury. Biochem. J. 144: 115-122.

36. Toole, B. P., A. H. Kang, R. L. Trelstad, and J. Gross. 1972. Collagen heterogeneity within different growth regions of long bones of rachitic and nonrachitic chicks. Biuchem. J. 127 : 715-720.

37. Cintron, C. 1974. Hydroxylysine glycosides in the collagen of normal and scarred rabbit corneas. Biochem. Biophys. Res. Commun. 60: 288-294.

38. Fietzek, P. P., and J. Rauterberg. 1975. Cyanogen bromide peptides of type III collagen: First sequence analysis demonstrates homology with type I collagen. FEBS (Fed. Eur. Biochem. Soc.) Lett. 49: 365-368. 